J. vet. Pharmacol. Therap. 29, 477-488, 2006.

\title{
Pharmacodynamic effects and pharmacokinetic profile of a long-term continuous rate infusion of racemic ketamine in healthy conscious horses
}

D. P. K. LANKVELD*

B. DRIESSEN ${ }^{\dagger}$

L. R. SOMA ${ }^{\dagger}$

P. J. MOATE ${ }^{\dagger}$

J. RUDY*

C. E. $\mathrm{UBOH}^{\dagger,+}$

P. VAN DIJK* \&

L. J. HELLEBREKERS*

*Equine Sciences Department, Faculty of Veterinary Medicine, Utrecht University, Utrecht, The Netherlands; ${ }^{\dagger}$ Department of Clinical Studies, School of Veterinary Medicine, University of Pennsylvania, Kennett Square, PA; ${ }^{\dagger}$ Pennsylvania Equine Toxicology \& Research Laboratory, Department of Chemistry,

West Chester University,

West Chester, PA, USA
Lankveld, D. P. K., Driessen, B., Soma, L. R., Moate, P. J., Rudy J., Uboh, C. E., van Dijk, P., Hellebrekers, L. J. Pharmacodynamic effects and pharmacokinetic profile of a long-term continuous rate infusion of racemic ketamine in healthy conscious horses. J. vet. Pharmacol. Therap. 29, 477-488.

Ketamine (KET) possesses analgesic and anti-inflammatory activity at subanesthetic doses, suggesting a benefit of long-term KET treatment in horses suffering from pain, inflammatory tissue injury and/or endotoxemia. However, data describing the pharmacodynamic effects and safety of constant rate infusion (CRI) of KET and its pharmacokinetic profile in nonpremedicated horses are missing. Therefore, we administered to six healthy horses a CRI of $1.5 \mathrm{mg} / \mathrm{kg} / \mathrm{h}$ KET over $320 \mathrm{~min}$ following initial drug loading. Cardiopulmonary parameters, arterial blood gases, glucose, lactate, cortisol, insulin, nonesterified fatty acids, and muscle enzyme levels were measured, as were plasma concentrations of KET and its metabolites using liquid chromatographytandem mass spectrometry (LC-MS/MS). Levels of sedation and muscle tension were scored. Respiration and heart rate significantly increased during the early infusion phase. Glucose and cortisol significantly varied both during and after infusion. During CRI all horses scored 0 on sedation. All but one horse scored 0 on muscle tension, with one mare scoring 1 . All other parameters remained within or close to physiological limits without significant changes from pre-CRI values. The mean plasma concentration of KET during the $1.5 \mathrm{mg} / \mathrm{kg} / \mathrm{h}$ KET CRI was $235 \mathrm{ng} / \mathrm{mL}$. The decline of its plasma concentration-time curve of both KET and norketamine (NKET) following the CRI was described by a twocompartmental model. The metabolic cascade of KET was NKET, hydroxynorketamine (HNK), and 5,6-dehydronorketamine (DHNK). The KET median elimination half-lives $\left(t_{1 / 2 \alpha}\right.$ and $\left.t_{1 / 2 \beta}\right)$ were 2.3 and $67.4 \mathrm{~min}$, respectively. The area under the KET plasma concentration-time curve (AUC), elimination was $76.0 \mu \mathrm{g} \cdot \mathrm{min} / \mathrm{mL}$. Volumes of $\mathrm{C}_{1}$ and $\mathrm{C}_{2}$ were 0.24 and $0.79 \mathrm{~L} / \mathrm{kg}$, respectively. It was concluded that a KET CRI of $1.5 \mathrm{mg} / \mathrm{kg} / \mathrm{h}$ can safely be administered to healthy conscious horses for at least $6 \mathrm{~h}$, although a slight modification of the initial infusion rate regimen may be indicated. Furthermore, in the horse KET undergoes very rapid biotransformation to NKET and HNK and DHNK were the major terminal metabolites.

(Paper received 27 September 2005; accepted for publication 25 July 2006)

Bernd Driessen, University of Pennsylvania, School of Veterinary Medicine, Department of Clinical Studies-New Bolton Center, 382 W. Street Rd., Kennett Square, PA 19348, USA. E-mail: driessen@vet.upenn.edu

\section{INTRODUCTION}

Ketamine $[( \pm)$ 2-o-chlorpophenyl, 2-methylamino, cyclohexanone; KET], a noncompetitive $N$-methyl-D-aspartate (NMDA) receptor antagonist, has been in use in equine practice for both the induction and maintenance of general anesthesia in horses for many years (Muir et al., 1977; Muir \& Sams, 1992). It causes a characteristic anesthetic state often referred to as dissociative anesthesia. Based on the observation that NMDA receptors are involved in the modulation of intractable visceral and somatic pain (Woolf \& Thompson, 1991; Coderre et al., 1993; Fisher et al., 2000), KET as one of the few clinically available NMDA receptor antagonist drugs have been tested and found to be effective as an analgesic in both laboratory and human clinical 
studies (Quian et al., 1996; Schmid et al., 1999; Guirimand et al., 2000; Wang et al., 2000; Laurido et al., 2001; Suzuki et al., 2001; Castroman \& Ness, 2002a,b; Hughes et al., 2002; Hocking \& Cousins, 2003; Strigo et al., 2005).

Experimental evidence is surfacing that indicates that KET also exhibits potent anti-inflammatory actions including reduced chemotactic activation of neutrophils and suppression of leukocyte-dependent production of cytokines such as tumor necrosis factor $\alpha$ (TNF- $\alpha$ ), interleukin-6 (IL-6), and IL-8 through either direct or indirect mechanisms (Koga et al., 1994; Zahler et al., 1999; Taniguchi et al., 2001, 2003, 2004; Mazar et al., 2005). In an equine macrophage cell line, KET inhibited LPS-induced TNF- $\alpha$ and IL- 6 responses in a concentration-dependent manner (Lankveld et al., 2005), demonstrating that this drug could have cytokine-modulating effects in horses suffering from systemic inflammation and endotoxemia. Considering the concentrationdependent influence and the fact that elevated plasma cytokine levels have been detected in horses for several hours after onset of endotoxemia (MacKay et al., 1991; Morris et al., 1992), one must assume that KET has to be administered over extended periods of time and at relatively high doses to be clinically effective.

Ketamine's analgesic and anti-inflammatory effects, shown at sub-anesthetic doses in other species, may prove useful in pain treatment and/or intra- and postoperative intensive care of the horse. Despite those attractive properties the risk of side effects, mainly affecting the central nervous system (excitement/sedation) and increased skeletal muscle tone (catatonia), may preclude a wider use of KET for long-term treatment in the conscious horse.

We undertook the present study in preparation for future investigations analyzing the immunomodulatory role of KET and its metabolites in vivo and focused on three main goals. First, we wanted to determine the safety of a constant rate infusion (CRI) of racemic KET in conscious horses by evaluating its effects on central and peripheral nervous activity, cardiopulmonary function, metabolic and endocrinological homeostasis, choosing an infusion dose likely to achieve plasma concentrations that are known to exhibit analgesic and cytokine-modulating effects. Secondly, we wanted to expand the current knowledge regarding the metabolism of KET by using a modified version of a recently developed liquid chromatography-mass spectrometry (LC-MS/ MS) technique (Moore et al., 2001) to identify all metabolites that are formed in the horse. Thirdly, we wanted to determine the pharmacokinetic parameters for KET following steady-state infusion as those data are not yet reported for the conscious horse and are important for future dose tailoring.

\section{MATERIALS AND METHODS}

\section{Animals}

Six healthy, adult Dutch Warmblood horses [600 $\pm 35 \mathrm{~kg}$ body weight (mean $\pm \mathrm{SD}$ ); $13 \pm 6$ years; four mares, two geldings] in good body condition were studied after approval by the Utrecht
University Ethics and Animal Research Committee. No food or water was withheld before or during the experiment.

\section{Animal preparation and instrumentation}

Two hours prior to experimentation, horses were restrained in stocks and a 12-G, $8 \mathrm{~cm}$ polytetrafluoroethylene catheter (Intraflon $2^{\circledR}$; Vygon Nederland BV, Veenendaal, The Netherlands) was placed aseptically into the left and right jugular veins. Using lidocaine-prilocaine cream (EMLA ${ }^{\circledR}$; Astra Pharmaceutica BV, Zoetermeer, The Netherlands) and an aseptic technique, a 14-G, 4.5-cm over the needle catheter (Arterial Cannula with FloSwitch ${ }^{\circledR}$; Becton \& Dickenson, Swindon, UK) was inserted percutaneously into the left facial artery for arterial blood sampling and arterial blood pressure (ABP) measurements. Respiration rate (RR) was based on visual observation. The heart rate (HR) was recorded using a digital heart rate monitor (Polar HorseTrainer S610 ${ }^{\mathrm{TM}}$; Polar Electro Europe BV, Fleurier, Switzerland). Systolic, diastolic and mean ABPs (SAP, DAP, MAP) were monitored using a disposable blood pressure transducer (DTXTM Plus DT-XX, Becton \& Dickinson Critical Care Systems Pte Ltd, Singapore) connected to a multichannel recorder (Hewlett-Packard, Utrecht, The Netherlands). After restricting the horse's head height to its normal, relaxed standing position, the zero level of the transducer was set at the estimated level of the heart base. Transducers were calibrated before each experimental period for each horse.

\section{Experimental protocol and measured parameters}

All studies were started at 10:00 AM to avoid the possible variation imposed by circadian rhythm changes which have been identified in horses placed in a stable environment and accustomed to routine patterns of management (Irvine \& Alexander, 1994). Following complete instrumentation horses were allowed to adapt to the new environment for $60 \mathrm{~min}$. A jugular venous infusion of racemic KET (Narketan ${ }^{\circledR} 100 \mathrm{mg}$ / $\mathrm{mL}$, Vétoquinol BV, 's-Hertogenbosch, The Netherlands), dissolved in $3 \mathrm{~L}$ of $0.9 \% \mathrm{NaCl}$ solution, was started in all animals at 10:00 AM $(t=0 \mathrm{~min})$ at a rate of $4.8 \mathrm{mg} / \mathrm{kg} / \mathrm{h}$ using a computer-controlled infusion device (ARGUS414; Adquipment Medical B.V., Spijkenisse, The Netherlands). The infusion rate was then reduced in a step-wise fashion every $10 \mathrm{~min}$ to 3.6 , $3.0,2.4$, and finally $1.5 \mathrm{mg} / \mathrm{kg} / \mathrm{h}$ was maintained for $320 \mathrm{~min}$ (Fig. 1).

All parameters including RR, HR, SAP, DAP, MAP, with the exception of muscle enzymes, were determined 15 min before starting KET infusion to collect baseline values. Baseline plasma concentrations of muscle enzymes were determined $24 \mathrm{~h}$ before start of infusion. Subsequent measurements of physiological and blood parameters were conducted at variable intervals. The level of sedation and muscle tension were subjectively scored each time RR and HR were recorded. A five-point scale (0-4) was used to score the level of sedation: $0=$ no sedative effect, $1=$ reduced alertness with no other signs, 2 = drowsiness and slight drop of the head, 3 = marked drowsiness and drop of the head, 


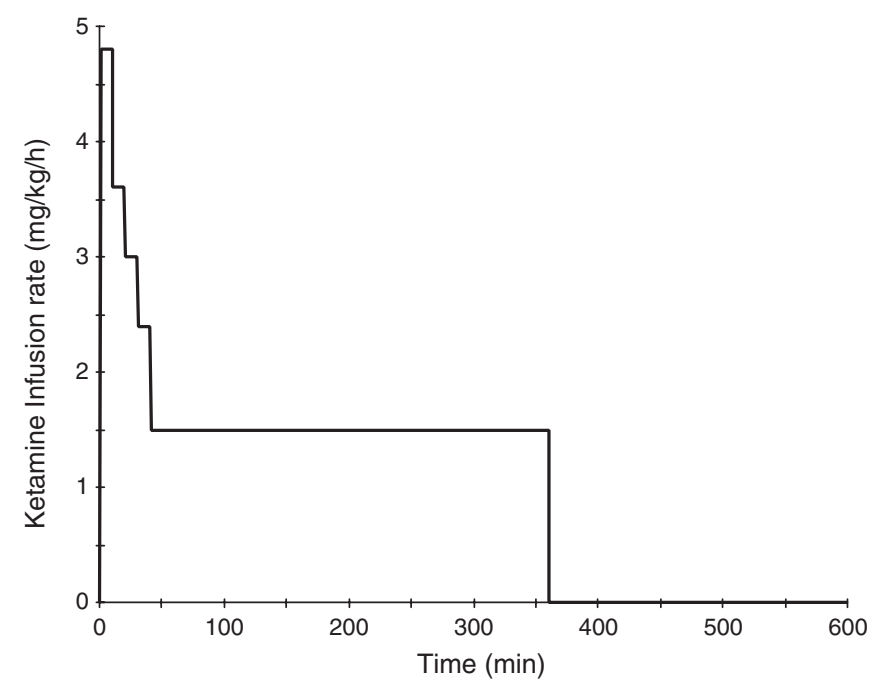

Fig. 1. An intravenous infusion (CRI) of ketamine was started in each horse at 10:00 Am (time 0) at a loading rate of $4.8 \mathrm{mg} / \mathrm{kg} / \mathrm{h}$ and then reduced in a stepwise fashion every 10 min till finally a rate of $1.5 \mathrm{mg} /$ $\mathrm{kg} / \mathrm{h}$ was achieved which was then kept constant for $320 \mathrm{~min}$.

4 = recumbency (Kerr et al., 1996). A four-point (0-3) scale was used to score muscle tension: $0=$ muscle relaxation present in trunk and limbs, $1=$ muscle twitching present in some regions of trunk and limbs, $2=$ muscle twitching present over the majority of trunk and limbs and $3=$ muscle rigidity present over the majority of trunk and limbs (Gómez de Segura et al., 1998).

Blood samples for arterial $\mathrm{pH}(\mathrm{pH})$, partial pressures of $\mathrm{O}_{2}$ $\left(\mathrm{P}_{\mathrm{a}} \mathrm{O}_{2}\right)$ and $\mathrm{CO}_{2}\left(\mathrm{P}_{\mathrm{a}} \mathrm{CO}_{2}\right)$ and venous glucose and lactate levels were collected in heparinized syringes $(2 \mathrm{~mL})$ and immediately analyzed using a blood gas analyzer (ABL System 605; Radiometer, Copenhagen, Denmark). Heparinized venous blood samples were collected for measurement of plasma lactate dehydrogenase (LDH), creatine phosphokinase (CK) and aspartate aminotransferase (ASAT) levels. Blood samples were centrifuged immediately following collection and then plasma harvested and stored at $-20{ }^{\circ} \mathrm{C}$ prior to analysis. Plasma concentrations of $\mathrm{LDH}, \mathrm{CK}$, and ASAT were determined later by a colorimetric technique. Venous heparinized blood samples (8 mL) for cortisol, insulin and nonesterified fatty acid (NEFA) determinations were centrifuged immediately following collection, plasma harvested and then stored at $-20{ }^{\circ} \mathrm{C}$ pending analysis. Plasma insulin and cortisol concentrations were measured by use of commercial radioimmunoassay kits (Coat-A-Count ${ }^{\circledR}$ Insulin and Coat-A-Count ${ }^{\circledR}$ Cortisol; Diagnostic Products Corporation, Los Angeles, CA, USA), and NEFA concentrations were measured by colorimetry using a Randox kit (Randox Laboratories Ltd, Ardmore, UK). All three kits were validated for samples obtained from horses (Van der Kolk et al., 1995).

Two blood samples for measurement of KET and its metabolites in plasma were collected prior to drug administration and at $9,19,29,39,45,50,90,150,210,270,330,359,361$,
$363,365,368,372,380,395,410,430,450,480,510,540$, 570 , and $600 \mathrm{~min}$ after start of KET infusion. Samples were centrifuged, serum harvested and then stored at $-70{ }^{\circ} \mathrm{C}$ prior to LC-MS/MS analysis.

\section{Liquid chromatography-mass spectrometry (LC-MS/MS) analysis}

Dichloromethane (Cert ACS/HPLC grade), isopropanol (ACS/ HPLC grade), ammonium hydroxide (ACS grade), $16 \times 125$ screw cap culture tubes, and $16 \times 100$ screw cap tubes were obtained from Scientific Equipment Company (SECO, Aston, PA, USA). Formic acid (Supra-Pure, 99\%) was obtained from VWR Scientific (Bridgeport, NJ, USA). Water and acetonitrile (Optima grade) were obtained from Fisher Scientific (Pittsburgh, PA, USA). Calibration standards for ketamine $\mathrm{HCl}$, norketamine (NKET) $\mathrm{HCl}$, and $\mathrm{d}_{4}$-ketamine (internal standard) were obtained from Cerriliant Corp. (Austin, TX, USA). All reagents, solutions, and standards were prepared from these materials.

Unknowns, calibrators, and controls were prepared by adjusting $0.1 \mathrm{~mL}$ samples to $\mathrm{pH}$ of 9.0 with $2 \mathrm{~mL}$ of $\mathrm{pH} 9.0$ ammonium formate placed in screw cap tubes. Internal standard $\mathrm{d}_{4}$-ketamine $(100 \mu \mathrm{L})$ was added to all tubes (unknowns, calibrators and controls) except negative control. Calibrators and controls were prepared by using $0.1 \mathrm{~mL}$ aliquots of previously prepared spiked plasma (1-1000 ng/mL). All tubes were then extracted with $5 \mathrm{~mL}$ of dichloromethane:isopropanol (10:1) on gentle mixing (rotorack) for $10 \mathrm{~min}$. The sample tubes were centrifuged for $5 \mathrm{~min}$ at $2500 \mathrm{~g}$, after which the organic solvent was transferred to clean, dry, labeled culture tubes and evaporated at $50{ }^{\circ} \mathrm{C}$ under a gentle stream of nitrogen. The dried samples were reconstituted with $0.1 \mathrm{~mL} 0.1 \%$ formic acid, and then transferred to clean, labeled auto sampler vials fitted with $0.2 \mathrm{~mL}$ limited volume inserts and capped.

Previously screened negative equine plasma sample was used for the creation of calibrators and positive controls. Ten concentrations ranging from 1 to $1000 \mathrm{ng} / \mathrm{mL}$ were prepared. Aliquots of $0.1 \mathrm{~mL}$ of each sample were used to maintain the analysis within the linear range of the instrumentation with sensitivity sufficient for the current studies.

Analysis was conducted on an integrated liquid chromatograph-mass spectrometer. The liquid chromatograph with auto sampler was a Surveyor (Thermo Electron Corp., San Jose, CA, USA) and the mass spectrometer was a Deca XP plus (Thermo Electron Corp.) operated in positive ion electrospray mode. The chromatographic column was an ACE 5 C-18 analytical column ( $3 \times 50 \mathrm{~mm}, 5$ micron) and the integrated guard column an ACE 3 C-18 $(2.1 \times 12.5 \mathrm{~mm})$. The LC mobile phase was $2.33 \mathrm{~mm}$ formic acid ( $\mathrm{pH}$ 6.0) and acetonitrile, run over a 10min convex gradient from $100 \%$ aqueous to $100 \%$ organic at $0.2 \mathrm{~mL} / \mathrm{min}$. The mass spectrometer utilized atmospheric pressure ionization in positive ion electrospray mode, and data were acquired by reconstructed ion chromatograms of targeted precursor ions in MS mode. Data reconstruction and quantification was performed using Xcalibur software, version 1.3 (Thermo Electron Corp.). 
Chromatographic conditions were determined in MS mode by extraction of the relevant precursor ion species $\left[\mathrm{M}+\mathrm{H}^{+}\right]$for the respective analytes. Peak purity was determined by examination of the relative isotopic abundance of the precursor ion and the chlorine isotope $\left[\mathrm{M}+\mathrm{H}^{+}+2\right]$ ion. This was necessary to determine full chromatographic separation of isobaric analytes with either $\left[\mathrm{M}+\mathrm{H}^{+}\right]$or $\left[\mathrm{M}+\mathrm{H}^{+}+2\right]$ masses at the masses of $\mathrm{m} / \mathrm{z} 224,226,240$, and 242.

The MS mode allowed the determination of analytes for which no reference compound exists for the construction of calibration curves. Calibration of hydroxynorketamine (HNK) and 5,6dehydronorketamine (DHNK) utilized the NKET calibration curve. The ionization efficiencies of MS mode precursor ion production are more parallel than the tandem MS/MS mode, which would be dependent upon both the efficiencies of product ion generation, as well as the product ions chosen for quantitative determination. Standard operating procedures for the quantification of analytes met requirements for accreditation by the American Association for Laboratory Accreditation and International Guidelines (ISO/IEC 17025, Geneva, Switzerland, 1999).

\section{Pharmacokinetic analysis}

Plasma concentration-time curve of KET and its metabolites, NKET, HNK, and DHNK following i.v. infusion of KET were analyzed using standard linear compartmental analysis (WinSAAM) (Boston et al., 1981; Stefanovski et al., 2003). Pharmacokinetics of KET and its metabolites were described by a sixcompartment model (Fig. 2). The infusion of KET was into compartment $1\left(\mathrm{C}_{1}\right)$ and the distribution of KET and NKET were described by two-compartment inter-compartmental transfer rate constants $k_{1,2}, k_{2,1}, k_{3,4}$, and $k_{4,3}$.

The rate of metabolism and appearance of NKET from KET was estimated by $k_{1,3}$ and the rate of direct elimination and metabolism of NKET to HNK and DHNK were described by $k_{3,0}$, $k_{3,5}$, and $k_{3,6}$, the sum of which in effect describes the total elimination of NKET. The elimination of HNK and DHNK from $\mathrm{C}_{5}$ and $\mathrm{C}_{6}$ was described by fractional rate constants $k_{5,0}$ and $k_{6,0}$.

The inter-compartmental fractional transfer rates were directly estimated by using the following equations:

$$
\dot{Y}=-L Y+U,
$$

where $Y$ is a matrix describing the quantity of drug present in each of the compartments considered, $\dot{Y}$ is the derivative of $Y, L$ is a matrix of the fractional rate constants describing the intercompartmental flow of drug, and $U$ is a matrix of the instantaneous input rates into each compartment. $L$ is related to the eigenvalues and eigenvectors by:

$$
L=A \alpha A^{-1},
$$

where $A$ is the matrix of eigenvectors (boundary conditions), $\alpha$ is a matrix of the eigenvalues (exponential slope constants) and $A^{-1}$ is the inverse of $A$ (Wastney et al., 1999). The WinSAAM software is uniquely refined to permit direct translation between the exponential and equivalent compartmental model forms. The eigenvalues were estimated using WinSAAM utilizing Eqns 1

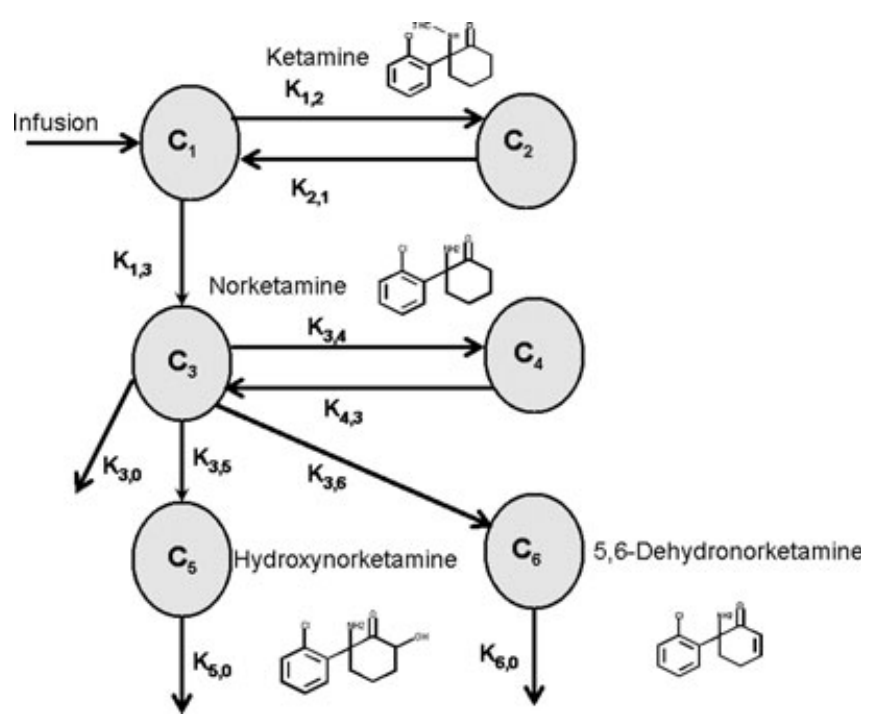

Fig. 2. The six-compartment model describing the distribution of ketamine (KET) and its metabolites following the intravenous infusion of ketamine. The infusion of KET was into compartment $1\left(\mathrm{C}_{1}\right)$ and the distribution and elimination of KET and norketamine (NKET) were described by two-compartment inter-compartmental transfer rate constants $k_{1,2}, k_{2,1}, k_{3,4}$ and $k_{4,3}$. The rate of metabolism and appearance of NKET from KET was estimated by $k_{1,3}$. The rate of direct renal elimination of NKET and metabolism of NKET to hydroxynorketamine (HNK) and 5,6-dehydronorketamine (DHNK) were described by $k_{3,0}, k_{3,5}$, and $k_{3,6}$, the sum of which in effect describes the total elimination of NKET. The elimination of HNK and DHNK from $\mathrm{C}_{5}$ and $\mathrm{C}_{6}$ were described by fractional rate constants $k_{5,0}$ and $k_{6,0}$. Volumes $(\mathrm{V})$ of $\mathrm{C}_{3}, \mathrm{C}_{5}$, and $\mathrm{C}_{6}$ were set equal to $\mathrm{C}_{1}$.

and 2. Half-lives $\left(t_{1 / 2}\right)$ were calculated as the natural $\log _{2}$ divided by the fractional rate constants.

The weights $W_{k}$, applied in the fitting process utilized the fractional standard deviation (FSD) of the data, and were in the form of $W_{k}=1 /\left[C \times Q_{\mathrm{O}(k)} \times 2\right]$, where $Q_{\mathrm{O}(k)}$ is the $k$ th observed datum and $C$ is its FSD. The fitting process (iterations) ceased when the improvement in the sums of squares of the last iteration is $<1 \%$ (Wastney et al., 1999).

The total area under the plasma KET and metabolites concentration curves $\left(A U C_{0}^{610}\right)$ from 0 to $610 \mathrm{~min}$ was calculated by trapezoid rule. Time to maximum plasma concentration $\left(T_{\max }\right)$ and maximum plasma concentration $\left(C_{\max }\right)$ were obtained directly from the experimental data. Volumes (V) of $\mathrm{C}_{3}, \mathrm{C}_{5}$, and $\mathrm{C}_{6}$ were set equal to $\mathrm{C}_{1}$. The volumes of $\mathrm{C}_{2}$ and $\mathrm{C}_{3}$ were calculated as:

$\mathrm{V}_{2}=\mathrm{V}_{1} \frac{k_{1,2}}{k_{2,1}} \quad$ and $\quad \mathrm{V}_{3}=\mathrm{V}_{1} \frac{k_{3,4}}{k_{4,3}}$.

Clearance $(\mathrm{Cl})$ from each compartment was estimated as: $\mathrm{Cl}=\mathrm{V} k$.

\section{Statistical analysis}

Statistical analysis was performed using the SPSS $^{\odot} 12.01$ statistical package (SPSS Inc., Chicago, IL, USA). Pharmacody- 
namic data and the plasma concentrations of KET and its metabolites, NKET, HNK, and DHNK, were analyzed using a repeated measures analysis of variance and the Huynh-Feldt test statistic to adjust for sphericity and were expressed as mean \pm standard deviation (SD). When significant a paired $t$-test was used to compare differences with baseline values. Pharmacokinetic parameter estimates of KET and metabolites were expressed as median and range. Differences were considered to be significant when $P<0.05$

\section{RESULTS}

Cardiovascular, metabolic and endocrine effects

In all horses RR and HR significantly increased during the early infusion phase but after $20 \mathrm{~min}$, when the KET infusion rate was decreased to $3.6 \mathrm{mg} / \mathrm{kg} / \mathrm{h}$, values returned to baseline and remained stable for the remainder of the experiment, reaching a significant minimum for RR at $30 \mathrm{~h}$ (Table 1). Systolic arterial pressure, DAP, MAP and arterial blood gas tensions were collected in five horses only as in one horse arterial catheterization was not successful. Despite initial mild blood pressure increases and subsequent increases toward the end of KET infusion period none of the time points were statistically significant from control (Table 1). The $\mathrm{pH}, \mathrm{P}_{\mathrm{a}} \mathrm{O}_{2}$, and $\mathrm{P}_{\mathrm{a}} \mathrm{CO}_{2}$ were within physiological range throughout most of the infusion period; only $\mathrm{P}_{\mathrm{a}} \mathrm{CO}_{2}$ showing significant difference from baseline at $360 \mathrm{~min}$ of KET infusion.
Plasma lactate, insulin and NEFA concentrations remained within physiological limits, with the only exception of a significant decrease of plasma NEFA concentrations at $30 \mathrm{~h}$ post-infusion (Table 2). Throughout the entire experiment plasma glucose concentrations remained slightly above the physiological range (3.9-5.6 mmol/L). Plasma cortisol concentrations varied throughout the experimental period.

\section{Behavioral effects}

All horses started shifting weight from one front leg to the other within 5-10 min after start of infusion and continued to show this behavior for 20-30 min. During KET CRI none of the horses displayed any sedative effects. On the contrary, upon subjective evaluation three of six horses showed an increase in alertness during the 6-h infusion period.

\section{Skeletal muscle}

All but one horse scored 0 on muscle tension. One mare scored 1 at 20 and $30 \mathrm{~min}$ following start of KET infusion (Table 2). There were no significant changes in plasma LDH, CK and ASAT concentrations $3 \mathrm{~h}$ after the start of infusion.

\section{Ketamine pharmacokinetics and metabolism}

The median and range of the inter-compartmental fractional rate constants and pharmacokinetic parameter estimates for the i.v. infusion of KET and its metabolites are shown in Tables $3 \& 4$.

Table 1. Cardiopulmonary and blood-gas parameters prior to, during, and following ketamine constant rate infusion in conscious horses

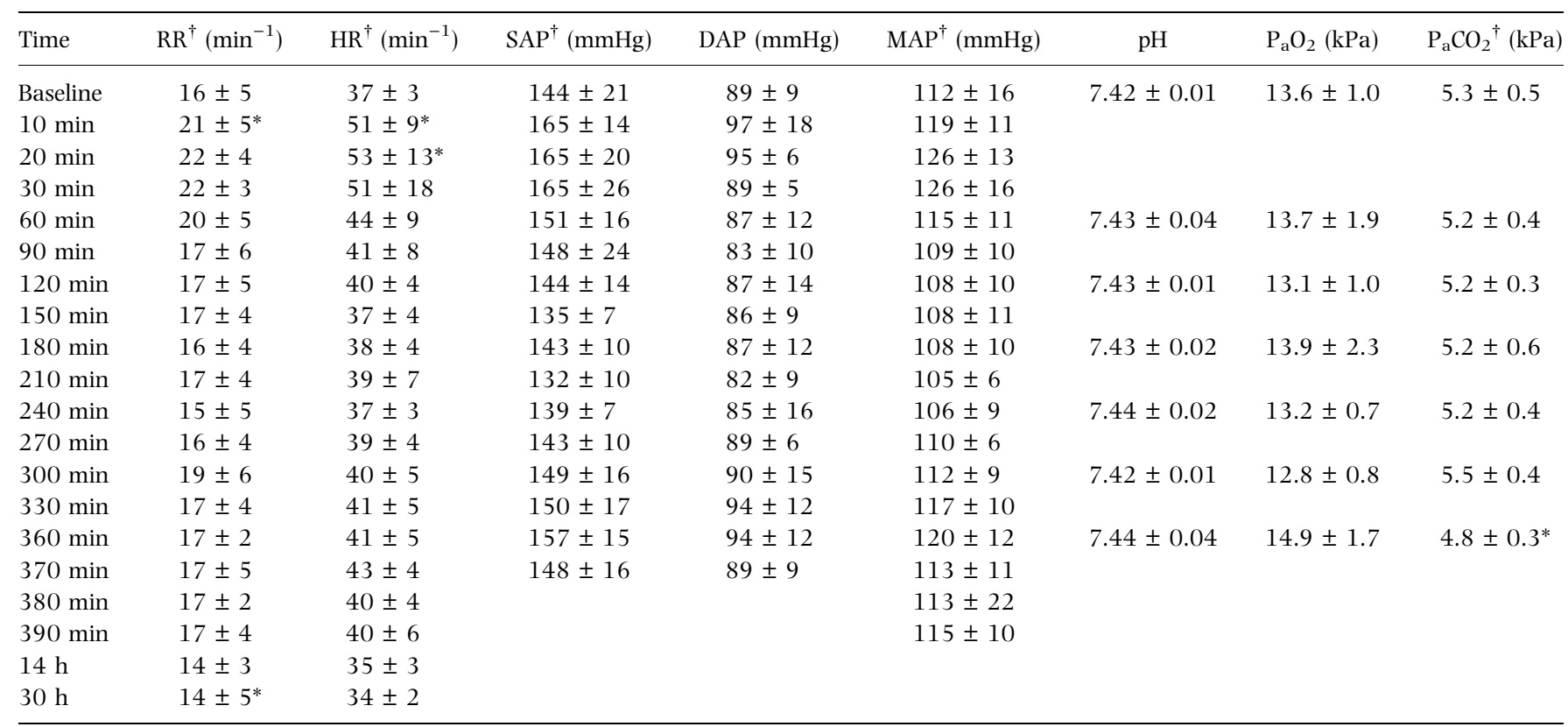

Values are expressed as mean $\pm \mathrm{SD}$.

$\mathrm{RR}=$ respiration rate; $\mathrm{HR}=$ heart rate; $\mathrm{SAP}=$ systolic arterial pressure; $\mathrm{DAP}=$ diastolic arterial pressure, $\mathrm{MAP}=\mathrm{mean}$ arterial pressure; $\mathrm{P}_{\mathrm{a}} \mathrm{O}_{2}=$ arterial partial pressure of oxygen; $\mathrm{P}_{\mathrm{a}} \mathrm{CO}_{2}=$ arterial partial pressure of carbon dioxide.

${ }^{\dagger}$ Parameters changing significantly from baseline over time based on repeated measures analysis of variance and Huynh-Feldt tests.

*Values significantly different (based on paired $t$-test) from baseline recorded 15 min prior to start of ketamine infusion: $P<0.05$. 
Table 2. Lactate, glucose, insulin, cortisol, nonesterified fatty acid (NEFA), and muscle enzyme levels prior to, during, and following ketamine constant rate infusion in conscious horses

\begin{tabular}{|c|c|c|c|c|c|c|c|c|}
\hline Time (h) & Lactate $(\mathrm{mmol} / \mathrm{L})$ & Glucose $^{\dagger}(\mathrm{mmol} / \mathrm{L})$ & Insulin (pmol/L) & $\operatorname{Cortisol}^{\dagger}(\mathrm{nmol} / \mathrm{L})$ & $\mathrm{NEFA}^{\dagger}(\mathrm{mmol} / \mathrm{L})$ & LDH (IU/L) & ASAT (IU/L) & CK (IU/L) \\
\hline Baseline & $0.7 \pm 0.3$ & $7.2 \pm 0.8$ & $393 \pm 339$ & $287 \pm 91$ & $0.23 \pm 0.16$ & $538 \pm 151$ & $165 \pm 50$ & $152 \pm 63$ \\
\hline 1 & $0.7 \pm 0.3$ & $5.9 \pm 1.1^{*}$ & $218 \pm 172$ & $201 \pm 56^{*}$ & $0.38 \pm 0.09$ & & & \\
\hline 2 & $0.8 \pm 0.3$ & $6.0 \pm 0.5^{*}$ & $250 \pm 169$ & $178 \pm 46^{*}$ & $0.28 \pm 0.16$ & & & \\
\hline 3 & $0.7 \pm 0.3$ & $5.9 \pm 0.3^{*}$ & $235 \pm 160$ & $144 \pm 34^{*}$ & $0.20 \pm 0.07$ & $683 \pm 465$ & $179 \pm 50$ & $175 \pm 94$ \\
\hline 4 & $0.6 \pm 0.2$ & $5.8 \pm 0.2^{*}$ & $187 \pm 151$ & $152 \pm 60^{*}$ & $0.20 \pm 0.08$ & & & \\
\hline 5 & $0.5 \pm 0.1$ & $5.7 \pm 0.5^{*}$ & $155 \pm 110$ & $168 \pm 76^{*}$ & $0.22 \pm 0.07$ & & & \\
\hline 6 & $0.6 \pm 0.2$ & $5.8 \pm 0.4^{*}$ & $127 \pm 88$ & $214 \pm 40$ & $0.27 \pm 0.11$ & $438 \pm 130$ & $163 \pm 63$ & $144 \pm 62$ \\
\hline 7 & $0.6 \pm 0.2$ & $5.8 \pm 0.6^{*}$ & $104 \pm 85$ & $271 \pm 49$ & $0.27 \pm 0.12$ & & & \\
\hline 8 & $0.7 \pm 0.1$ & $6.0 \pm 0.9^{*}$ & $148 \pm 125$ & $201 \pm 55^{*}$ & $0.25 \pm 0.17$ & & & \\
\hline 10 & $0.8 \pm 0.1$ & $6.0 \pm 0.3^{*}$ & $151 \pm 75$ & $133 \pm 48^{*}$ & $0.11 \pm 0.05$ & $567 \pm 137$ & $165 \pm 33$ & $158 \pm 43$ \\
\hline 14 & $0.7 \pm 0.1$ & $5.6 \pm 0.4^{*}$ & $134 \pm 56$ & $121 \pm 32^{*}$ & $0.08 \pm 0.01$ & & & \\
\hline 22 & $0.7 \pm 0.1$ & $5.8 \pm 0.7^{*}$ & $192 \pm 100$ & $204 \pm 33$ & $0.10 \pm 0.02$ & & & \\
\hline 30 & $0.8 \pm 0.2$ & $5.8 \pm 0.3^{*}$ & $183 \pm 74$ & $135 \pm 50^{*}$ & $0.07 \pm 0.03^{*}$ & $440 \pm 185$ & $189 \pm 41$ & $130 \pm 40$ \\
\hline
\end{tabular}

Values are expressed as mean $\pm \mathrm{SD}$.

NEFA = nonesterified fatty acids; $\mathrm{LDH}=$ lactate dehydrogenase; $\mathrm{CK}=$ creatine kinase; ASAT = aspartate aminotransferase.

†Parameters changing significantly from baseline over time based on repeated measures analysis of variance and Huynh-Feldt tests.

*Values significantly different (based on paired $t$-test) from baseline recorded 15 min prior to start of ketamine infusion: $P<0.05$.

Table 3. Pharmacokinetic parameter estimates of ketamine and metabolites following an i.v. infusion of ketamine in $n=6$ horses

\begin{tabular}{|c|c|c|}
\hline Parameter & Median & Range \\
\hline \multicolumn{3}{|l|}{ Ketamine } \\
\hline$t_{1 / 2 \alpha}(\min )$ & 2.34 & $1.67-2.86$ \\
\hline$t_{1 / 2 \beta}(\min )$ & 67.45 & $59.2-85.6$ \\
\hline$t_{1 / 2 k_{\mathrm{t} 1}}(\min )$ & 2.96 & $2.29-3.31$ \\
\hline $\mathrm{V}_{1}(\mathrm{~mL} / \mathrm{kg})$ & 242.2 & $163.7-335.8$ \\
\hline $\mathrm{V}_{2}(\mathrm{~mL} / \mathrm{kg})$ & 786.2 & $329.4-1437.7$ \\
\hline $\mathrm{Cl}_{1}(\mathrm{~mL} / \mathrm{min} / \mathrm{kg})$ & 53.0 & $36.6-88.7$ \\
\hline$A U C_{0}^{610}(\mu \mathrm{g} \cdot \mathrm{min} / \mathrm{mL})$ & 76.0 & $48.0-105.3$ \\
\hline \multicolumn{3}{|l|}{ Norketamine } \\
\hline$t_{1 / 2 \alpha}(\min )$ & 10.46 & $5.0-15.3$ \\
\hline$t_{1 / 2 \beta}(\min )$ & 160.69 & $80.2-307.6$ \\
\hline$t_{1 / 2 k_{\mathrm{t} 3}}(\mathrm{~min})$ & 7.53 & $5.4-9.0$ \\
\hline $\mathrm{V}_{4}(\mathrm{~mL} / \mathrm{kg})$ & 755.1 & $547.3-1558.2$ \\
\hline $\mathrm{Cl}_{3}(\mathrm{~mL} / \mathrm{min} / \mathrm{kg})$ & 23.3 & $15.9-42.9$ \\
\hline$A U C_{0}^{610}(\mu \mathrm{g} \cdot \mathrm{min} / \mathrm{mL})$ & 160.8 & $94.1-232.9$ \\
\hline \multicolumn{3}{|l|}{ Hydroxynorketamine } \\
\hline$t_{1 / 2 k_{\mathrm{e} 5}}(\min )$ & 56.95 & $33.6-64.4$ \\
\hline $\mathrm{Cl}_{5}(\mathrm{~mL} / \mathrm{min} / \mathrm{kg})$ & 3.1 & $2.0-6.8$ \\
\hline$A U C_{0}^{610}(\mu \mathrm{g} \cdot \mathrm{min} / \mathrm{mL})$ & 372.9 & $304.5-449.3$ \\
\hline \multicolumn{3}{|l|}{ 5,6-Dehydronorketamine } \\
\hline$t_{1 / 2 k_{\mathrm{e}}}(\mathrm{min})$ & 43.26 & $27.6-46.5$ \\
\hline $\mathrm{Cl}_{6}(\mathrm{~mL} / \mathrm{min} / \mathrm{kg})$ & 4.4 & $2.6-8.1$ \\
\hline$A U C_{0}^{610}(\mu \mathrm{g} \cdot \mathrm{min} / \mathrm{mL})$ & 396.6 & $251.1-568.2$ \\
\hline
\end{tabular}

$t_{1 / 2 \alpha}$ and $t_{1 / 2 \beta}=$ compartmental half-lives; $t_{1 / 2 k_{\mathrm{t}}}=$ transfer half-lives from $\mathrm{C}_{1}$ and $\mathrm{C}_{3} ; t_{1 / 2 k_{\mathrm{e}}}=$ elimination half-lives from $\mathrm{C}_{5}$ and $\mathrm{C}_{6} ; \mathrm{V}_{1}$ and $\mathrm{V}_{2}=$ apparent volumes of $\mathrm{C}_{1}$ and $\mathrm{C}_{2} ; A U C=$ area under the curve; $\mathrm{Cl}=$ clearance from $\mathrm{V}_{1}, \mathrm{~V}_{3}, \mathrm{~V}_{5}$, and $\mathrm{V}_{6}$.

The plasma concentration of KET progressively decreased as the rate of infusion was decreased and this change was significant $(P<0.02)$ at the end of the $2.4 \mathrm{mg} / \mathrm{kg} / \mathrm{h}$ infusion period (Table 5; Fig. 3). Conversion of KET to NKET was quantified at the first sampling time and there was a significant increase in the
Table 4. Median and range of calculated inter-compartmental transfer and elimination rate constants $(k)$ and fractional standard deviation of the estimates (FSD) of the six-compartment model describing the pharmacokinetics of ketamine and metabolites following the i.v. infusion of ketamine in $n=6$ horses

\begin{tabular}{lccc}
\hline Parameter & Median & Range & FSD \\
\hline Ketamine & & & \\
$k_{1,2}\left(\mathrm{~min}^{-1}\right)$ & 0.046 & $0.015-0.060$ & 0.034 \\
$k_{2,1}\left(\mathrm{~min}^{-1}\right)$ & 0.013 & $0.009-0.015$ & 0.015 \\
$\quad k_{1,3}\left(\mathrm{~min}^{-1}\right)$ & 0.235 & $0.209-0.303$ & 0.017 \\
Norketamine & & & \\
$\quad k_{3,4}\left(\min ^{-1}\right)$ & 0.033 & $0.015-0.140$ & 0.057 \\
$k_{4,3}\left(\mathrm{~min}^{-1}\right)$ & 0.010 & $0.006-0.019$ & 0.058 \\
$k_{3,5}\left(\min ^{-1}\right)$ & 0.032 & $0.021-0.062$ & 0.019 \\
$k_{3,6}\left(\min ^{-1}\right)$ & 0.044 & $0.036-0.066$ & 0.018 \\
$\quad k_{3,0}\left(\min ^{-1}\right)^{*}$ & 0.013 & $0.000-0.038$ & 0.068 \\
Hydroxynorketamine & & & \\
$\quad k_{5,0}\left(\min ^{-1}\right)$ & 0.012 & $0.011-0.021$ & 0.016 \\
5,6 -Dehydronorketamine & & & \\
$k_{6,0}\left(\min ^{-1}\right)$ & 0.016 & $0.015-0.025$ & 0.016 \\
\hline
\end{tabular}

NKET plasma concentrations $(P<0.02)$ at the end of first infusion period of KET $(4.8 \mathrm{mg} / \mathrm{kg} / \mathrm{h})$. The NKET concentrations gradually declined and paralleled the concentration changes of KET (Fig. 4). Conversion of NKET to HNK and DHNK was also rapid and continuous over the CRI (Table 5; Figs $3 \& 4$ ). There were significant increases in the plasma concentration of HNK $(P<0.04)$ and DHNK $(P<0.01)$ at the end of the second infusion period of KET $(3.6 \mathrm{mg} / \mathrm{kg} / \mathrm{h})$ (Table 5). There were no significant differences in the plasma concentrations of HNK and DHNK at the end of the CRI.

Once the CRI was discontinued KET concentrations decreased rapidly, reaching plasma levels approximately one-tenth of those measured during CRI within 90 min. A six-compartment model best described the decline of the plasma concentration-time curve of KET and its metabolites (Fig. 2). A bi-exponential 
Table 5. Plasma concentrations (mean \pm SD) of ketamine (KET) and its metabolites norketamine (NKET), hydroxynorketamine (HNK), and 5,6-dehydronorketamine (DHNK) at the end of each infusion period ( $n=6$ horses)

\begin{tabular}{lccccc}
\hline $\begin{array}{l}\text { Infusion } \\
\text { rate }(\mathrm{mg} / \mathrm{kg} / \mathrm{h})\end{array}$ & Time (min) & KET $(\mathrm{ng} / \mathrm{mL})$ & NKET $(\mathrm{ng} / \mathrm{mL})$ & HNK $(\mathrm{ng} / \mathrm{mL})$ & DHNK $(\mathrm{ng} / \mathrm{mL})$ \\
\hline 4.8 & 9 & $407 \pm 183$ & $351 \pm 154^{*}$ & $184 \pm 57$ & $159 \pm 62$ \\
3.6 & 19 & $368 \pm 87$ & $471 \pm 137$ & $315 \pm 63^{*}$ & $347 \pm 74^{*}$ \\
3.0 & 29 & $352 \pm 88$ & $538 \pm 115$ & $460 \pm 91$ & $535 \pm 99$ \\
2.4 & 39 & $288 \pm 80^{*}$ & $510 \pm 120$ & $506 \pm 83$ & $649 \pm 144$ \\
1.5 & 372 & $230 \pm 120$ & $489 \pm 137$ & $920 \pm 169$ & $1001 \pm 238$ \\
\hline
\end{tabular}

*Values significantly different from measurements at previous infusion rate and sampling time, respectively: $P<0.05$.

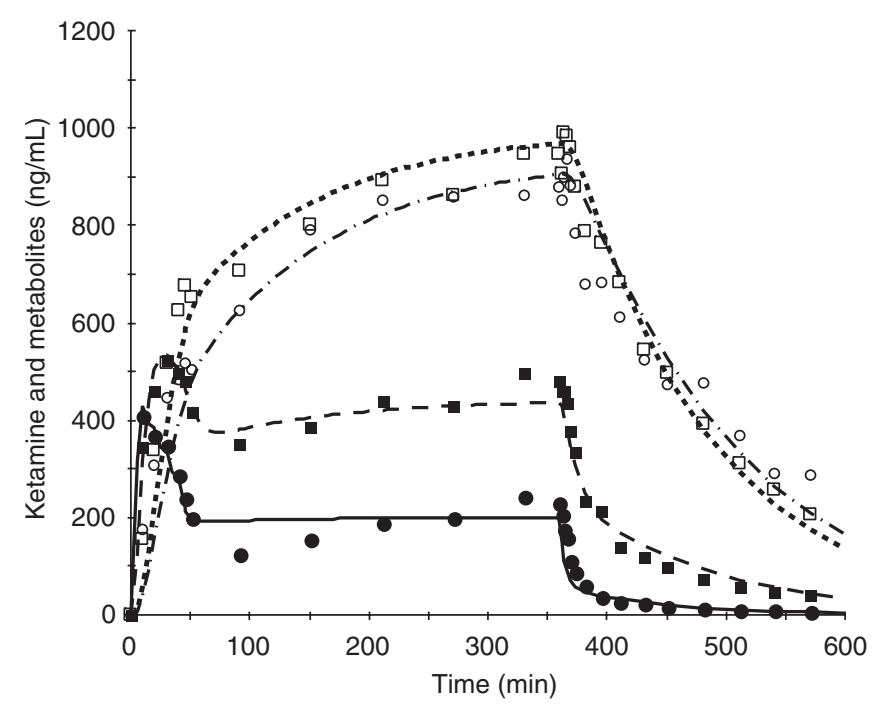

Fig. 3. Plasma concentrations and the corresponding curves of best fit of ketamine (-), norketamine ( $\square--$ ), hydroxynorketamine $(\bigcirc-\cdots-\cdot)$, and 5,6-dehydronorketamine $(\cdots)$ during and following i.v. ketamine infusion. Symbols represent mean values from $n=6$ horses.

equation best described the data for KET and NKET. The initial distributive $(\alpha)$ phase of KET was characterized by an estimated half-life of $2.3 \mathrm{~min}\left(t_{1 / 2 \alpha}\right)$ and the slower elimination $(\beta)$ phase by a half-life of $67.4 \mathrm{~min}\left(t_{1 / 2 \beta}\right)$ (Table 3$)$. Thus, KET distributed very rapidly from the central $\left(\mathrm{C}_{1}\right.$; plasma and blood-rich tissues) to the peripheral tissue compartments $\left(\mathrm{C}_{2}\right)$ with an intercompartmental transfer rate constant $k_{1,2}$ of $0.046 \mathrm{~min}^{-1}$. The apparent volumes of $\mathrm{C}_{1}, \mathrm{C}_{2}$ and $\mathrm{C}_{4}$ were estimated as 242.2, 786.2, and $755.1 \mathrm{~mL} / \mathrm{kg}$, respectively and the estimated clearances of $\mathrm{C}_{1}, \mathrm{C}_{3}, \mathrm{C}_{5}$, and $\mathrm{C}_{6}$ are also shown (Table 3). Like the parent drug, NKET rapidly interchanged between the central and peripheral compartments $\left(\mathrm{C}_{3}\right.$ and $\left.\mathrm{C}_{4}\right)$. The elimination of the secondary metabolites HNK and DHNK were described by a mono-exponential equation (Fig. 3; Table 4).

\section{DISCUSSION}

Pharmacodynamic effects of racemic ketamine during long-term infusion in conscious horses

The present data indicate that in healthy conscious horses KET at a rate of $1.5 \mathrm{mg} / \mathrm{kg} / \mathrm{h}$ can be safely administered over prolonged periods of time. The CRI rate of $1.5 \mathrm{mg} / \mathrm{kg} / \mathrm{h}$ chosen in this study was based on previously published data in horses, which were receiving an i.v. induction dose of $2.2 \mathrm{mg} / \mathrm{kg}$ and returned to consciousness when plasma KET concentrations fell to or below $1 \mu \mathrm{g} / \mathrm{mL}$ (Waterman et al., 1987). Thus, to be prepared for future investigations analyzing dose-dependent immunomodulatory effects of KET in the horse, we aimed at achieving relatively high plasma concentrations, yet without the risk of causing loss of consciousness. A $0.8 \mu \mathrm{g} / \mathrm{mL}$ plasma concentration appeared to be the upper limit as it was close to but still safely below those associated with anesthetic effects. Applying the previously reported pharmacokinetic variables in the horse (Waterman et al., 1987) (Table 6), a computer program for therapeutic drug monitoring (Beal SL, Sheiner LB: NONMEM Users Guides, NONMEM Project Group, University of California, San Francisco, CA, USA) predicted a KET CRI dose of $1.5 \mathrm{mg} / \mathrm{kg} / \mathrm{h}$ as appropriate for achieving this goal. To reach steady-state concentrations a CRI can either be preceded by a bolus injection or by an initially higher infusion rate followed by a stepwise decrease of the dosage. We opted for the latter as it carried the least risk of resulting in peak plasma concentrations in excess of $1 \mu \mathrm{g} / \mathrm{mL}$.

During the $1.5 \mathrm{mg} / \mathrm{kg} / \mathrm{h}$ KET CRI plasma KET concentrations averaged $235 \mathrm{ng} / \mathrm{mL}$ (range: 118-277 ng/mL; Figs 3 \& 4), which were far below the plasma concentrations predicted by the computer program. This significant discrepancy might have been caused by a variety of reasons. Foremost, pharmacokinetic properties may change when KET is administered in combination with other drugs, leading to altered metabolism, distribution and excretion of the compound (see below for more details).

Although plasma concentrations were far below the estimated concentration of $800 \mathrm{ng} / \mathrm{mL}$ evaluation of the recorded physiological and behavioral parameters suggests that the CRI rate chosen approaches the upper limit of what may be tolerated under clinical circumstances. Especially the infusion rates of 4.8 and $3.6 \mathrm{mg} / \mathrm{kg} / \mathrm{h}$, administered early during the infusion period, were associated with significant increases in RR, HR and ABP (Table 1). In addition, at these infusion rates, horses showed mild behavioral changes in the form of shifting weight from one front leg to the other, and some muscle twitching was recorded in both front legs of one horse. In addition, increased alertness observed in three of six horses during the 6-h KET infusion points toward increased central nervous activity caused by KET and warrants caution when infusing the drug at higher rates. 


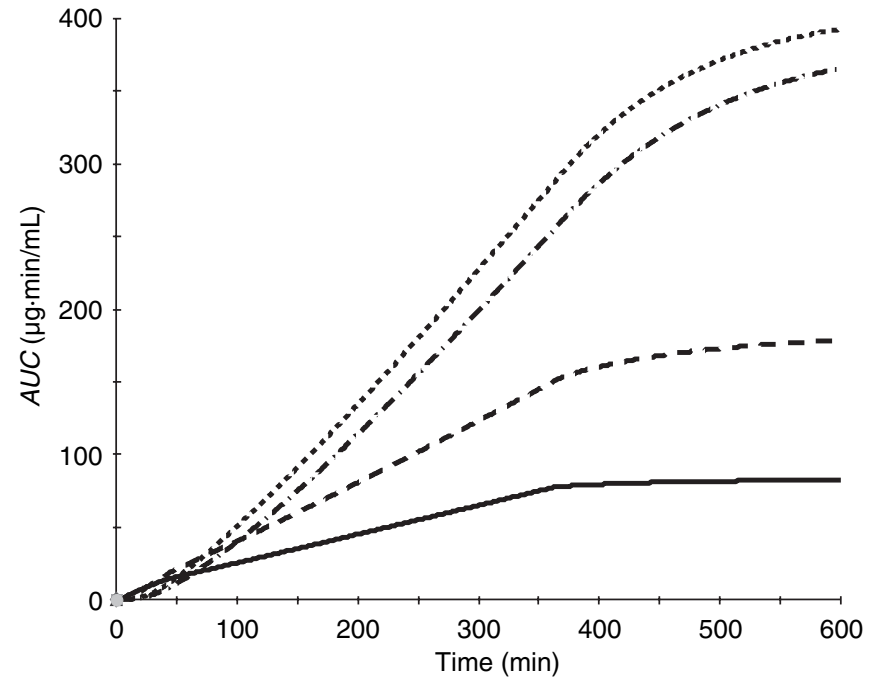

Fig. 4. Area under the curve $(A U C)$ values of ketamine and its metabolites during and following i.v. ketamine infusion. The AUC reflects the relative amount of metabolites to the parent compound (bottom to top: ketamine, norketamine, hydroxynorketamine, and 5,6-dehydronorketamine). Data from $n=6$ horses.

High baseline plasma glucose and cortisol concentrations might indicate a stress response induced by experimental environment and manipulations performed prior to KET infusion. One may also speculate that the increase in plasma cortisol concentration rather than the expected diurnal decrease and the remaining elevated plasma glucose concentrations during the experiment were the result of the KET CRI, even though other factors not controlled for in these experiments might have been responsible as well. As an indirect sympathomimetic drug, KET may cause elevated endogenous catecholamine levels and hence stimulate the release of plasma cortisol, subsequently leading to hyperglycemia caused by increased gluconeogenesis and/or insulin resistance. In order to evaluate any acute impact of
KET on skeletal muscle tissue integrity, plasma concentrations of LDH, ASAT and CK were measured. Creatinine phosphokinase has a high specificity for muscle damage. Therefore, the fact that for none of the enzymes plasma concentrations significantly changed and that both ASAT and CK remained within physiological limits suggests that KET, when administered at the infusion rates used in this study, had no significant impact on skeletal muscle activity and tissue integrity.

\section{Pharmacokinetics}

Clinically KET is used primarily as a short-acting anesthetic, most commonly administered in conjunction with $\alpha_{2}$ adrenoceptor agonists. Thus, in previous studies in the equine the drug was administered at anesthetic doses $(\geq 2.2 \mathrm{mg} / \mathrm{kg})$ following an i.v. injection of either xylazine $(1.1 \mathrm{mg} / \mathrm{kg})$ or detomidine $(20 \mu \mathrm{g} / \mathrm{kg})$ and its pharmacokinetic profile was determined under conditions of inhalant or total intravenous anesthesia (Kaka et al., 1979; Waterman et al., 1987; Nolan et al., 1996). Inhalant anesthetics (e.g. halothane) and anesthetic adjuvants (e.g. diazepam, secobarbital, alfentanil, xylazine) are known to slow redistribution and hepatic metabolism of KET in various animal species. Chronic KET administration is associated with induction of hepatic drugmetabolizing cytochrome $\mathrm{P}_{450}\left(\mathrm{CYP}_{450}\right)$ enzymes in laboratory animals (White et al., 1982; Waterman et al., 1987; Edwards et al., 2002). Moreover, protein binding of KET (Wright, 1982), stability of KET in blood samples (Hijazi et al., 2001), and accuracy of the analytical technique used to measure KET concentrations in plasma can be of influence. Thus, extrapolating previously obtained pharmacokinetic data for the use of long-term infusion of KET in otherwise nonpremedicated horses may not be appropriate. The present study is therefore the first to investigate in awake horses the distribution and metabolism of KET when administered in the form of a long-term infusion $(1.5 \mathrm{mg} / \mathrm{kg} / \mathrm{h})$.

Table 6. Pharmacokinetic data for racemic ketamine from comparative references

\begin{tabular}{|c|c|c|c|c|c|}
\hline \multirow[b]{2}{*}{ Species } & \multirow{2}{*}{$\begin{array}{l}\begin{array}{l}\text { Kaka et al. (1979) } \\
(n=4)\end{array} \\
\text { Horse }\end{array}$} & \multirow{2}{*}{$\begin{array}{l}\begin{array}{l}\text { Waterman et al. (1987) } \\
(n=10)\end{array} \\
\text { Horse }\end{array}$} & \multicolumn{2}{|c|}{$\begin{array}{l}\text { Schwieger et al. (1991) } \\
\qquad(n=4)\end{array}$} & \multirow{2}{*}{$\begin{array}{l}\text { Domino et al. (1982) } \\
\qquad(n=7) \\
\text { Human }\end{array}$} \\
\hline & & & & $\operatorname{Dog}$ & \\
\hline Ketamine dose & $2.2 \mathrm{mg} / \mathrm{kg}$ i.v. & $2.2 \mathrm{mg} / \mathrm{kg}$ i.v. & 10 mg/kg i.v. & $0.3 \mathrm{mg} / \mathrm{kg} / \mathrm{min} \mathrm{CRI}^{*}$ & $2.0-2.2 \mathrm{mg} / \mathrm{kg}$ i.v. \\
\hline $\mathrm{V}_{1}(\mathrm{~mL} / \mathrm{kg})$ & $212 \pm 24$ & $492 \pm 74$ & $810 \pm 135$ & n.d. & $50 \pm 17$ \\
\hline $\mathrm{V}_{2}(\mathrm{~mL} / \mathrm{kg})$ & $611 \pm 131$ & n.d. & n.d. & $2888 \pm 460$ & $157 \pm 47$ \\
\hline $\mathrm{V}_{\mathrm{ss}}(\mathrm{mL} / \mathrm{kg})$ & $1625 \pm 103$ & $611 \pm 131$ & $1370 \pm 205$ & n.d. & 2114 \\
\hline $\mathrm{Cl}(\mathrm{mL} / \mathrm{min} / \mathrm{kg})$ & $26.6 \pm 3.5$ & $31.1 \pm 2.3$ & $18.1 \pm 2.9$ & $13.9 \pm 2.5$ & 18.6 \\
\hline$t_{1 / 2 \alpha}(\min )$ & 2.9 & $2.89 \pm 0.25$ & $7.7 \pm 0.9$ & n.d. & $0.49 \pm 0.08$ \\
\hline$t_{1 / 2 \beta}(\min )$ & 42 & $65.84 \pm 3.46$ & $121.9 \pm 4.6$ & $140.6 \pm 19.8$ & $158 \pm 36$ \\
\hline$k_{1,2}\left(\min ^{-1}\right)$ & $0.093 \pm 0.020$ & $0.164 \pm 0.024$ & n.d. & n.d. & n.d. \\
\hline$k_{2,1}\left(\min ^{-1}\right)$ & $0.032 \pm 0.006$ & $0.042 \pm 0.005$ & n.d. & n.d. & n.d. \\
\hline
\end{tabular}

Data are presented as mean \pm SD.

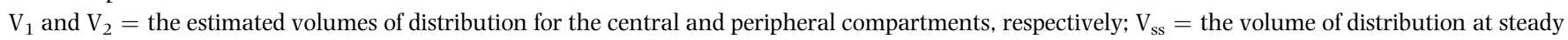

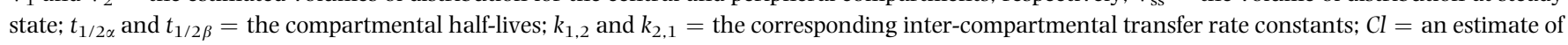
the total body clearance rate; n.d. = not determined.

*Initial ketamine loading dose of $26 \mathrm{mg} / \mathrm{kg}$ over $20 \mathrm{~min}$, followed by a constant rate infusion (CRI) for $5 \mathrm{~h}$.

†Data were analyzed using a three-compartment model. 
Pharmacokinetic variables $\left(t_{1 / 2 \alpha}, t_{1 / 2 \beta}, \mathrm{V}_{1}, \mathrm{~V}_{2}, \mathrm{Cl}\right)$ determined for infusion of KET were not very different from those previously reported in horses after i.v. bolus administration (Kaka et al., 1979; Waterman et al., 1987; Nolan et al., 1996) (compare Tables 3 \& 6). This observation coincides with findings in dogs (Schwieger et al., 1991), in which clearance ( $\mathrm{Cl})$ and elimination half-lives $\left(t_{1 / 2 \beta}\right)$ were similar between animals receiving a single i.v. dose or a CRI of KET (Tables 3 \& 6). Plasma concentrations only reached a stable plateau after $300 \mathrm{~min}$ of KET CRI (Fig. 3), confirming that for a true steady-state to occur constant drug infusion must be maintained for a period of at least five elimination half-lives (Wagner, 1974; Gibaldi \& Perrier, 1982). The average plasma KET concentration during $1.5 \mathrm{mg} / \mathrm{kg} / \mathrm{h}$ KET infusion was $235 \mathrm{ng} / \mathrm{mL}$ and thus was far below levels needed to produce anesthesia (i.e. $1.2 \pm 0.2 \mu \mathrm{g} / \mathrm{mL}$; Kaka et al., 1979), but was within the range of concentrations that exhibit analgesic effects in humans (Hocking \& Cousins, 2003; Strigo et al., 2005) and anti-inflammatory actions in vitro (Lankveld et al., 2005). Similar to the results obtained in previous pharmacokinetic studies in the equine (Kaka et al., 1979; Waterman et al., 1987; Nolan et al., 1996) and other species (White et al., 1982), following termination of the CRI plasma KET concentrations declined bi-exponentially, and the disposition of KET and NKET in all six horses was best described using a two-compartment model, which had previously been described for KET in the horse (Kaka et al., 1979; Waterman et al., 1987), dog (Kaka \& Hayton, 1980), cat (Baggot \& Blake, 1976), and other species including man as well (White et al., 1982). As with an i.v. bolus during CRI of KET the initial distribution phase from the central (plasma and vessel-rich tissues; $\mathrm{C}_{1}$ ) to the peripheral tissue compartments $\left(C_{2}\right)$ occurs with a very short half-life $\left(t_{1 / 2 \alpha}\right)$ of approximately 2-3 min, followed by a much slower elimination phase, representing both metabolism and renal elimination and occurring with a half-life $\left(t_{1 / 2 \beta}\right)$ of about $1 \mathrm{~h}$. The apparent volume of distribution of the peripheral compartments $\left(C_{2}\right.$ and $\mathrm{C}_{4}$ ) was approximately 3.2 times greater than that of $\mathrm{C}_{1}$ (Table 3), which has been observed also in other species such as the dog (Kaka \& Hayton, 1980), cat (Baggot \& Blake, 1976), and human (Domino et al., 1982; Geisslinger et al., 1993). The large volume of the second compartment is characteristic for the strong lipid solubility of weak bases such as KET (White et al., 1982) and hence confirms the high affinity of the drug for many tissues other than plasma.

Ketamine is metabolized extensively by the hepatic $\mathrm{CYP}_{450}$ enzyme system in all species including the horse (Livingston \& Waterman, 1978; White et al., 1982; Delatour et al., 1991). However, total body clearance (Table 3) appears to exceed hepatic blood flow in the horse (Kaka et al., 1979) and renal KET excretion occurs only in the immediate period post-i.v. administration (Sams \& Pizzo, 1987), indicating that also extrahepatic pathways in organs such as the kidney, lung, and gut may participate in the elimination of KET from plasma, as has been demonstrated in the rat (Edwards \& Mather, 2001). In many species including the horse (White et al., 1982; Delatour et al., 1991), initial hepatic biotransformation via N-demethylation produces NKET (metabolite I) that then can be hydroxylated at one or more positions in the cyclohexanone ring to form HNK, which in turn can be conjugated to more water-soluble glucuronide derivatives and be excreted by the kidneys (Fig. 2). As the hydroxylated metabolites of NKET are unstable $e x$ vivo at higher temperatures, they were thought to rapidly undergo further oxidation (thermal dehydration) to DHNK, which had been identified as the predominant final metabolite also found in equine serum and urine following i.v. KET administration (Sams \& Pizzo, 1987; Seay et al., 1993).

Although called metabolite II (White et al., 1982; Waterman et al., 1987), the in vivo existence of DHNK as a true metabolite has long been questioned by investigators suggesting that formation of DHNK could be the result of an analytical artifact associated with the gas-liquid chromatography-mass spectrometry (GC-MS) that was commonly used at the time for detection and quantification of KET and metabolites in plasma and urine (White et al., 1982; Moore et al., 2001). It was thought that under the harsh chemical conditions of the GC method, involving benzene extraction of a strongly alkalinized sample followed by heptafluorobutyric anhydride derivatization in the presence of pyridine, HNK and other $\alpha$ - and $\beta$-hydroxy ketones would be easily converted to the respective dehydro compounds (Moore et al., 2001). The use of the more benign LC-MS in this study has been shown to eliminate much of the thermal component of DHNK generation. The difference between the two available methodologies can be quantified by comparison of DHNK levels obtained by GC-MS and LC-MS/MS. Additionally, the lack of any GC-MS reports of HNK speaks directly to the facility with which this conversion can take place. The elevated temperatures of GC-MS instrumentation and the harsh conditions of chemical derivatization, both seem more than sufficient to produce DHNK from HNK. The present study shows high levels of both HNK and DHNK, which have parallel slopes of appearance and disappearance (Fig. 3). However, even using our LC-MS/MS method to minimize the thermal conversion, ion source conditions and electrospray ion formation and ejection processes may still be sufficient to facilitate the enol-mediated dehydration process, probably leading to some degree of artificial formation of DHNK in addition to in vivo-generated DHNK metabolite. The detection by our methodology of both enolic positional hydroxylations (which are chromatographically resolved - but are reported as a single species) and measurement of consistently higher DHNK than HNK levels (Figs 3 \& 4) lend further support to this idea and underscore some limitations of the LC-MS/MS methodology that could result in an overestimation of the quantity of DHNK formed during biotransformation.

Independent of the possible analytical bias toward the production of DHNK, the LC-MS/MS technique allowed us for the first time to describe the complete metabolic cascade of KET in the horse (Figs $2 \& 4$; Tables $3 \& 4$ ). Already in the first blood sample drawn after starting the KET infusion (i.e. at $9 \mathrm{~min}$ ) all three metabolites (NKET, HNK, and DHNK) were detected. During the initial loading dose infusion of KET, NKET was the predominant metabolite detected, however, by the time the infusion was changed to a constant infusion at $1.5 \mathrm{mg} / \mathrm{kg} / \mathrm{h}$ 
HNK and DHNK had become the predominant metabolites detected in plasma, with concentrations rapidly surmounting plasma concentrations of the parent compound KET and metabolite NKET. These findings coincide with previous data in the horse demonstrating the detection of NKET in plasma as early as $2-5 \mathrm{~min}$ and peaking at $10-20 \mathrm{~min}$ following i.v. KET bolus administration (Waterman et al., 1987; Delatour et al., 1991). Rapid metabolism of KET to NKET and DHNK has also been described in other species including sheep (Waterman \& Livingston, 1978), dog (Kaka \& Hayton, 1980), and cat (Baggot \& Blake, 1976).

In order to better determine the rate at which NKET and other metabolites are formed, we administered in one additional adult horse an i.v. bolus of $1 \mathrm{mg} / \mathrm{kg}$ KET over a period of $10 \mathrm{~min}$ and collected blood samples at 1, 2, 4 and $8 \mathrm{~min}$ and extended the collection period to 12 and $24 \mathrm{~h}$ post-KET administration. Plasma concentrations of NKET were quantifiable at the 1-min sampling period and of HNK and DHNK at the 2-min sampling period (Fig. 5). Given these observations and KET's predicted distribution half-life $\left(t_{1 / 2 \alpha}\right)$ of $2.34 \mathrm{~min}$ (Table 3$)$, we can conclude that the conversion of KET to NKET must begin to occur within compartment $\left(\mathrm{C}_{1}\right)$, the plasma/extracellular fluid space (Fig. 2). As for KET, the plasma concentration-time curve for NKET also declined in a bi-exponential fashion, suggesting the use of a similar two-compartment model for NKET, with $\mathrm{C}_{3}$ representing the central and $\mathrm{C}_{4}$ the peripheral compartment of distribution. Individual distribution half-lives $\left(t_{1 / 2 \alpha}, t_{1 / 2 \beta}\right)$ and values, however, were quite different between KET and its first metabolite (Table 2). The model assumes that NKET rapidly distributes to compartment $\mathrm{C}_{3}$, which is thought to be of equal volume size as $\mathrm{C}_{1}$, and then interchanges with compartment $\mathrm{C}_{4}$. The median inter-compartmental transfer constant $k_{1,3}$ was

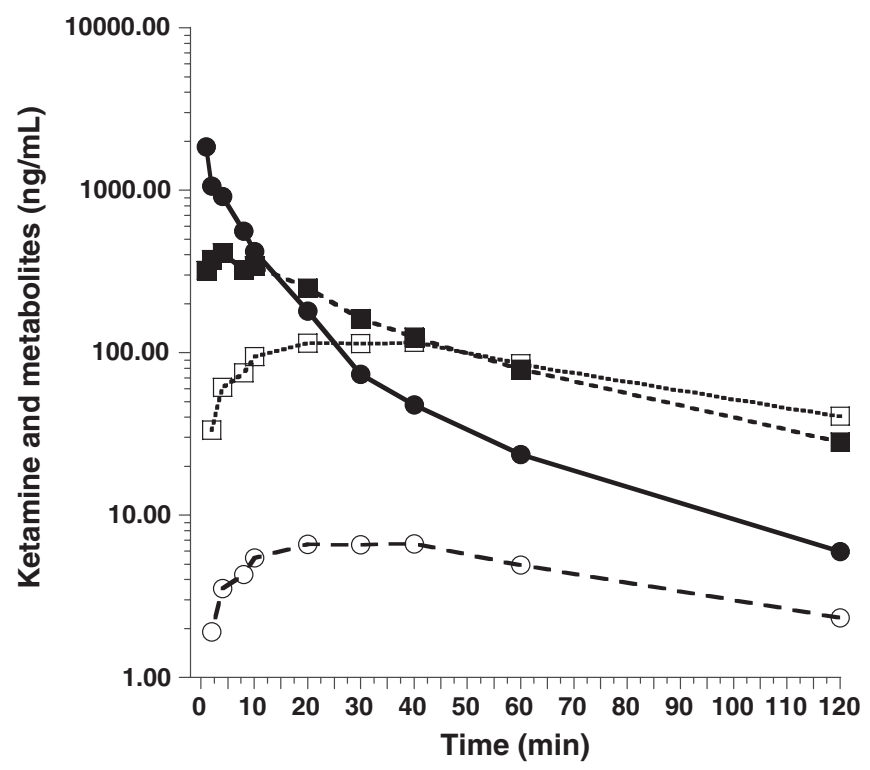

Fig. 5. Plasma concentrations (0-120 min) of ketamine (-), norketamine ( $\mathbf{-}--)$, hydroxynorketamine $(\bigcirc---)$, and 5,6-dehydronorketamine $(\cdots)$ following a single i.v. administration of ketamine $(1 \mathrm{mg} / \mathrm{kg})$ in one horse.
$0.235 \mathrm{~min}$, indicating how rapidly KET is metabolized to NKET. Our model suggests that NKET is eliminated both by conversion to HNK and DHNK and by renal excretion of the intact metabolite (Sams \& Pizzo, 1987).

In developing our six-compartment model to describe the distribution and metabolism of KET and its metabolites, we invoked the principle of parsimony. By this, we mean that we employed the minimum number of compartments, rate constants and assumptions that were necessary to describe all of the main features of the available experimental data and be consistent with the known pharmacokinetics KET. Our model does describe all the main features evident in the disposition curves of KET, NKET, HNK and DHNK during and following KET infusion, and $R^{2}$ values for KET and all metabolites in all individual horses were in excess of 0.90 . The robustness of our model is further evidenced by the fact that it could well describe the pattern of the disposition curves of KET, NKET, HNK and DHNK following a short-term (10 min) infusion of KET (Fig. 5). Despite the general success of our model, it must be acknowledged that during the period between 1 and $6 \mathrm{~h}$ into the CRI our model tends to under-predict the concentrations of KET and NKET. There may be several reasons for this under-prediction. First, in compartmental modeling of drug kinetics, it is generally assumed that when a drug is injected or infused into a compartment (generally the blood), it instantaneously disperses completely throughout that compartment. In reality, thorough mixing of drug throughout blood and extracellular fluid may take more than $1 \mathrm{~min}$. Thus immediately after a bolus injection or during constant infusion of drugs, plasma concentrations of the drug will necessarily be higher than predicted by models. Secondly, in our model, we assumed that the initial volumes of distribution for KET $\left(\mathrm{C}_{1}\right)$, NKET $\left(\mathrm{C}_{3}\right)$, HNK $\left(\mathrm{C}_{5}\right)$ and DHNK $\left(\mathrm{C}_{7}\right)$ are all equivalent. The general success of our modeling would suggest that this assumption is a good approximation. However, if this assumption is not true, then this could account for some of the discrepancies that we allude to. In support of this possibility, it is known that the metabolites of KET, especially HNK and DHNK are more hydrophilic than KET and consequently their initial volumes of distribution may be somewhat larger than that of KET (White et al., 1982; Edwards \& Mather, 2001). The third possibility that we must consider is that there could exist pathways of distribution and metabolism that we have not modeled. For example, one may contemplate the possibility that some NKET, HNK or DHNK may be reconverted to KET. Another possibility is that the metabolism of NKET might also occur from $\mathrm{C}_{4}$ (White et al., 1982; Edwards \& Mather, 2001).

The compartmental model presented here provides a complete conceptualization of the distribution and metabolism of KET and its metabolites. Furthermore, the model provides a means of making predictions of various regimens of KET administration and serves as a basis on which to make additional hypotheses regarding the metabolism of KET. We suggest that the model could be tested by further experimentation. For example, our assumption that there is no catabolism of NKET to KET could be tested by an experiment in which NKET is injected into the blood. The disposition of both KET and NKET can be described by two- 
compartment models, but the disposition of the more watersoluble metabolites HNK and DHNK can be described by just single exponential curves. Thus we can speculate that compartments $\mathrm{C}_{2}$ and $\mathrm{C}_{4}$ may represent the sequestration of KET and NKET, respectively within fatty tissue.

The contribution of KET's metabolites to the pharmacological effects of KET in the horse is unknown. Studies in sheep and humans suggest that NKET still exhibits up to $10 \%$ of the anesthetic activity of the parent compound, while DHNK has only about $1 \%$ of that activity (Waterman \& Livingston, 1978; White et al., 1982). Whether these metabolites have also analgesic or anti-inflammatory cannot be answered at this time.

In summary, a CRI of $1.5 \mathrm{mg} / \mathrm{kg} / \mathrm{h}$ KET can safely be administered to healthy conscious horses for at least $6 \mathrm{~h}$, although a slight modification of the initial infusion rate regimen may be indicated. Future experiments will reveal the safety and efficacy of long-term KET administration in equine patients suffering from severe pain and/or systemic inflammatory disease and the importance of KET's very rapid biotransformation to NKET, HNK and DHNK in those patients.

\section{ACKNOWLEDGMENTS}

The authors appreciate funding for parts of this study from the Pennsylvania Horse and Harness Racing Commissions and want to thank Marjorie Pollak and Anne Hess for their excellent technical assistance during the in vivo parts of the experiments. This study has been presented in part during the Autumn Meeting of the Association of Veterinary Anaesthetists, New Market, UK, September 21-23, 2005, and will be part of the PhD thesis of D.P.K.L.

\section{REFERENCES}

Baggot, J.D. \& Blake, J.W. (1976) Disposition kinetics of ketamine in the domestic cat. Archives Internationales de Pharmacodynamie et de Therapie, 220, 115-124.

Boston, R.C., Greif, P.C. \& Berman, M. (1981) Conversational SAAM - an interactive program for kinetic analysis of biological systems. Computer Methods and Programs in Biomedicine, 13, 111-119.

Castroman, P.J. \& Ness, T.J. (2002a) Ketamine, an N-methyl-D-aspartate receptor antagonist, inhibits the reflex responses to distension of the rat urinary bladder. Anesthesiology, 96, 1401-1409.

Castroman, P.J. \& Ness, T.J. (2002b) Ketamine, an N-methyl-D-aspartate receptor antagonist, inhibits the spinal neuronal responses to distension of the rat urinary bladder. Anesthesiology, 96, 1410-1419.

Coderre, T.J., Katz, J., Vaccarinou, A.L. \& Melzack, R. (1993) Contribution of central neuroplasticity to pathological pain: review of clinical and experimental evidence. Pain, 52, 259-285.

Delatour, P., Jaussaud, P., Courtot, D. \& Fau, D. (1991) Enantioselective $\mathrm{N}$-demethylation of ketamine in the horse. Journal of Veterinary Pharmacology and Therapeutics, 14, 209-212.

Domino, E.F., Zsigmond, E.K., Domino, L.E., Domino, K.E., Kothary, S.P. \& Domino, S.E. (1982) Plasma levels of ketamine and two of its metabolites in surgical patients using a gas chromatographic mass fragmentaographic assay. Anesthesia Analgesia, 61, 87-92.
Edwards, S.R. \& Mather, L.E. (2001) Tissue uptake of ketamine and norketamine enantiomers in the rat - indirect evidence for extrahepatic metabolic inversion. Life Sciences, 69, 2051-2066.

Edwards, S.R., Minto, C.F. \& Mather, L.E. (2002) Concurrent ketamine and alfentanil administration: pharmacokinetic considerations. British Journal of Anaesthesia, 88, 94-100.

Fisher, K., Coderre, T.J. \& Hagen, N. (2000) Targeting the N-methyl-Daspartate receptor for chronic pain management. Preclinical animal studies, recent clinical experience and future research directions. Journal of Pain and Symptom Management, 20, 358-373.

Geisslinger, G., Hering, W., Thomann, P., Knoll, R., Kamp, H.-D. \& Brine, K. (1993) Pharmacokinetics and pharmacodynamics of ketamine enantiomers in surgical patients using a stereoselective analytical method. British Journal of Anaesthesia, 70, 666-671.

Gibaldi, M. \& Perrier, D. (1982) Pharmacokinetics, 2nd edn. Marcel Dekker, New York.

Gómez de Segura, I.A., DeRossi, R., Santos, M., López San-Roman, J. \& Tendillo, F.J. (1998) Epidural injection of ketamine for perineal analgesia in the horse. Journal of Veterinary Anaesthesia, 27, 384-391.

Guirimand, F., Dupont, X., Brasseur, L., Chauvin, M. \& Bouhassira, D. (2000) The effects of ketamine on the temporal summation (wind-up) of the R(III) nociceptive flexion reflex and pain in humans. Anesthesia Analgesia, 90, 408-414.

Hijazi, Y., Bolon, M. \& Boulieu, R. (2001) Stability of ketamine and its metabolites norketamine and dehydronorketamine in human biological samples. Clinical Chemistry, 47, 1713-1715.

Hocking, G. \& Cousins, M.J. (2003) Ketamine in chronic pain management: an evidence-based review. Anesthesia Analgesia, 97, 1730-1739.

Hughes, A.M., Rhodes, J., Fisher, G., Sellers, M. \& Growcott, J.W. (2002) Assessment of the effect of dextromethorphan and ketamine on the acute nociceptive threshold and wind-up of the second pain response in healthy male volunteers. British Journal of Clinical Pharmacology, 53, 604-612.

Irvine, C.H. \& Alexander, S.L. (1994) Factors affecting the circadian rhythm in plasma cortisol concentrations in the horse. Domestic Animal Endocrinology, 11, 227-238.

Kaka, J.S. \& Hayton, W.L. (1980) Pharmacokinetics of ketamine and two metabolites in the dog. Journal of Pharmacokinetics and Biopharmaceutics, 8, 193-202.

Kaka, J.S., Klavano, P.A. \& Hayton, W.L. (1979) Pharmacokinetics of ketamine in the horse. American Journal of Veterinary Research, 50, 978-981.

Kerr, C.L., McDonell, W. \& Young, S.S. (1996) A comparison of romifidine and xylazine when used with diazepam/ketamine for short duration anesthesia in the horse. Canadian Veterinary Journal, 37, 601-609.

Koga, K., Ogata, M., Takenaka, I., Matsumoto, T. \& Shigematsu, A. (1994) Ketamine suppresses tumor necrosis factor-alpha activity and mortality in carrageenan sensitized endotoxin shock model. Circulatory Shock, 44, 160-168.

Lankveld, D.P.K., Bull, S., Van Dijk, P., Fink-Gremmels, J. \& Hellebrekers, L. (2005) Ketamine inhibits LPS-induced tumour necrosis factor-alpha and interleukin- 6 in an equine macrophage cell line. Veterinary Research, 36, 257-262.

Laurido, C., Pelissier, T., Perez, H., Flores, F. \& Hernandez, A. (2001) Effect of ketamine on spinal cord nociceptive transmission in normal and monoarthritic rats. Neuroreport, 12, 1551-1554.

Livingston, A. \& Waterman, A.E. (1978) The development of tolerance to ketamine in rats and the significance of hepatic metabolism. British Journal of Pharmacology, 64, 63-69.

MacKay, R.J., Merritt, M., Zertuche, J.M., Whittington, M. \& Skelly, L.A. (1991) MTumor necrosis factor activity in the circulation of horses given endotoxins. American Journal of Veterinary Research, 52, 533538. 
Mazar, J., Rogachev, B., Shaked, G., Ziv, N.Y., Czeiger, D., Chaimovitz, C., Zlotnik, M., Mukmenev, I. \& Byk, G. (2005) Involvement of adenosine in the antiinflammatory action of ketamine. Anesthesiology, 102, 1174-1181.

Moore, K.A., Sklerov, J., Levine, B. \& Jacobs, A.J. (2001) Urine concentrations of ketamine and norketamine following illegal consumption. Journal of Analytical Toxicology, 25, 583-588.

Morris, D.D., Crowe, N. \& Moldawer, L.L. (1992) Effect of experimentally induced endotoxemia on serum interleukin-6 activity in horses. American Journal of Veterinary Research, 53, 753-756.

Muir, W.W. \& Sams, R. (1992) Effects of ketamine infusion on halothane minimal alveolar concentration in horses. American Journal of Veterinary Research, 53, 1802-1806.

Muir, W.W., Skarda, R.T. \& Milne, D.W. (1977) Evaluation of xylazine and ketamine hydrochloride for anesthesia in horses. American Journal of Veterinary Research, 38, 195-201.

Nolan, A., Reid, J., Welsh, E., Flaherty, D., McCormack, R. \& Monteiro, A.M. (1996) Simultaneous infusions of propofol and ketamine in ponies premedicated with detomidine: a pharmacokinetic study. Research in Veterinary Science, 60, 262-266.

Quian, J., Brown, S.D. \& Carlton, S.M. (1996) Systemic ketamine attenuates nociceptive behaviors in a rat model of peripheral neuropathy. Brain Research, 715, 51-62.

Sams, R. \& Pizzo, P. (1987) Detection and identification of ketamine and its metabolites in horse urine. Journal of Analytical Toxicology, 11, 58-62.

Schmid, R.L., Sandler, A.N. \& Katz, J. (1999) Use and efficacy of low-dose ketamine in the management of acute postoperative pain: a review of current techniques and outcomes. Pain, 82, 111-125.

Schwieger, I.M., Szlam, F. \& Hug, C.C., Jr (1991) The pharmacokinetics and pharmacodynamics of ketamine in dogs anesthetized with enflurane. Journal of Pharmacokinetics and Biopharmaceutics, 19, 145-156.

Seay, S.S., Aucoin, D.P. \& Tyczkowska, K.L. (1993) Rapid high-performance liquid chromatographic method for the determination of ketamine and its metabolite dehydronorketamine in equine serum. Journal of Chromatography, 620, 281-287.

Stefanovski, D., Moate, P.J. \& Boston, R.C. (2003) WinSAAM: a windows-based compartmental modeling system. [Review] [18 refs]. Metabolism: Clinical \& Experimental, 52, 1153-1166.

Strigo, I.A., Duncan, G.H., Bushnell, C., Boivin, M., Wainer, I., Rosas, E.R. \& Persson, J. (2005) The effects of racemic ketamine on painful stimulation of skin and viscera in human subjects. Pain, 113, 255264.

Suzuki, R., Matthews, E.A. \& Dickenson, A.H. (2001) Comparison of the effects of MK-801, ketamine and memantine on responses of spinal dorsal horn neurones in a rat model of mononeuropathy. Pain, 91, 101-109.

Taniguchi, T., Shibata, K. \& Yamamoto, K. (2001) Ketamine inhibits endotoxin-induced shock in rats. Anesthesiology, 95, 928-932.

Taniguchi, T., Takemoto, Y., Kanakura, H. \& Yamamoto, K. (2003) The dose-related effects of ketamine on mortality and cytokine responses to endotoxin-induced shock in rats. Anesthesia Analgesia, 97, 1769-1772.

Taniguchi, T., Kanakura, H., Takemoto, Y. \& Yamamoto, K. (2004) The antiinflammatory effects of ketamine in endotoxemic rats during moderate and mild hypothermia. Anesthesia Analgesia, 98, 11141120.

Van der Kolk, J.H., Wensing, T., Kalsbeek, H.C. \& Breukink, H.J. (1995) Laboratory diagnosis of equine pituitary pars intermedia adenoma. Domestic Animal Endocrinology, 12, 35-39.

Wagner, J.G. (1974) A safe method for rapidly achieving plasma cconcentration plateaus. Clinical Pharmacology and Therapeutics, 16, $691-700$

Wang, Y., Huang, C., Cao, Y. \& Han, J.S. (2000) Repeated administration of low dose ketamine for the treatment of monoarthritic pain in the rat. Life Sciences, 67, 261-267.

Wastney, M.E., Patterson, B.H., Linares, O.A., Greif, P.C. \& Boston, R.C. (1999) Investigating Biological Systems Using Modeling: Strategies and Software. 129 pp. Academic Press, New York.

Waterman, A. \& Livingston, A. (1978) Studies on the distribution and metabolism of ketamine in sheep. Journal of Veterinary Pharmacology and Therapeutics, 1, 141-147.

Waterman, A.E., Robertson, S.A. \& Lane, J.G. (1987) The pharmacokinetics of intravenously administered ketamine in the horse. Research in Veterinary Science, 42, 161-166.

White, P.F., Way, W.L. \& Trevor, A.J. (1982) Ketamine its pharmacology and therapeutic uses. Anesthesiology, 56, 119-136.

Woolf, C.J. \& Thompson, S.W. (1991) The induction and maintenance of central sensitization is dependent on N-methyl-D-aspartic acid receptor activation; implications for the treatment of post-injury pain hypersensitivity states. Pain, 44, 293-299.

Wright, M. (1982) Pharmacologic effects of ketamine in veterinary medicine. Journal of the American Veterinary Medical Association, 180, 1462-1471.

Zahler, S., Heindl, B. \& Becker, B.F. (1999) Ketamine does not inhibit inflammatory responses of cultured human endothelial cells but reduces chemotactic activation of neutrophils. Acta Anaesthesiologica Scandinavica, 43, 1011-1016. 